\title{
High temperature behavior of electrostatic precipitator ash from municipal solid waste combustors
}

\author{
Lydie Le Forestier $^{\mathrm{a}, *}$, Guy Libourel ${ }^{\mathrm{b}, \mathrm{c}}$ \\ a ISTO, UMR 6113 CNRS-Université d'Orléans, Polytech'Orléans, 8 rue Léonard de Vinci, \\ 45072 Orléans Cedex 2, France \\ ${ }^{\mathrm{b}}$ CRPG-CNRS, UPR 2300, BP 20, 54501 Vandouvre-lès-Nancy, France \\ ${ }^{\mathrm{c}}$ ENSG-INPL, BP 40, 54501 Vandœuvre-lès-Nancy, France \\ * Corresponding author \\ E-mail address: lydie.leforestier@univ-orleans.fr \\ Tel.: +33 238255393; fax: +33 238636488 \\ Journal of Hazardous Materials \\ Ms. Ref. No.: HAZMAT-D-07-00176 \\ Accepted manuscript
}




\begin{abstract}
Municipal solid waste (MSW) flue gas residues require further treatment prior to disposal or reuse, and vitrification is one of the main solidification-stabilization processes. This paper investigates the high temperature behavior of MSW flue gas residues, performed in laboratory experiments up to $1400^{\circ} \mathrm{C}$, and coupled with thermogravimetric analyses, X-ray diffraction, chemical and electron microprobe analyses. Melting temperatures of electrostatic precipitator (ESP) ash are in the range of $1202-1272{ }^{\circ} \mathrm{C}$, whereas semi-dry scrubber residues melt between 1900 and $2300{ }^{\circ} \mathrm{C}$. We show that the mean liquidus temperature of flue gas residues can be simply evaluated from their $\mathrm{CaO}$ content, by using the $\mathrm{CaO}-\mathrm{SiO}_{2}-\mathrm{Al}_{2} \mathrm{O}_{3}$ ternary diagram. For ESP ash, the liquidus phase is a $\mathrm{Zn}$-rich aluminous spinel, followed by anorthite at $1225^{\circ} \mathrm{C}$, and melilite at $1190{ }^{\circ} \mathrm{C}$. The total mass loss reaches 18 wt. $\%$ at $1300{ }^{\circ} \mathrm{C}$. Moreover, $90 \%$ of evaporation takes place below 1000 ${ }^{\circ} \mathrm{C}$, linked to evaporation of $\mathrm{C}, \mathrm{Cl}, \mathrm{S}, \mathrm{Na}, \mathrm{K}$, and of the toxic metals $\mathrm{Hg}, \mathrm{Cd}, \mathrm{Pb}, \mathrm{Cu}$. Due to the high partial pressure of chlorine during heating, chloride is the most probable form of evaporation for $\mathrm{Cd}, \mathrm{Pb}$, and $\mathrm{Cu}$. However, most of $\mathrm{Zn}, \mathrm{Cr}$, Ni, Sb and $\mathrm{Sn}$ remain in the vitrified product.
\end{abstract}

Keywords: Fly ash; Vitrification; Melting temperature; Evaporation; Toxic metals 


\section{Introduction}

Incineration is an efficient method for managing municipal solid wastes (MSW), achieving up to a $90 \%$ volume reduction, a 60 to $75 \%$ mass reduction, a destruction of pathogenic agents and a possible recovery of energy. Whatever MSW combustor used, combustion of MSW produces two kinds of solid residues: (i) bottom ashes recovered from the primary combustor, and (ii) residues recovered from the treatment of flue gas. Due to their high contents of pollutant elements [1-6], many studies have been devoted to the characterization of flue gas residues, and particularly of electrostatic precipitator (ESP) ashes. Since solid flue gas residues are subject to leaching during their storage [5,7-13], they are potentially toxic for the environment and thus require further treatment before their long-term disposal. The aim of this waste management is that the ash-like toxic material could be transformed into a durable solid with a minimal release of pollutants into the environment. The solidification-stabilization processes include (1) extraction using acid or other solvents, (2) cement-based processes and (3) vitrification (melting and solidification). The vitrification technology mainly consists in melting these hazardous ashes at approximately $1400{ }^{\circ} \mathrm{C}$ in a high-temperature furnace and cooling in order to solidify them again. Even if energetic costs are important, vitrification, by comparison with hydraulic binders, (1) reduces the volume of residue, (2) leads to complete destruction of toxic organic compounds, and (3) produces a relatively inert residue, constituted by glass and/or crystals, and known as slag. During the melting operation, the non-volatile metals are immobilized into the structure of the slag, whereas the volatile metals are mainly transferred by evaporation to the exhaust gas, and converted into gas cooler ash. According to the French legislation, the melted slags resulting from flue gas residues, previously considered as hazardous wastes, are now stored in disposals dedicated for inert wastes. Studies devoted to the long-term behavior of these slags are still in progress, and the use of melted slags as secondary raw materials like bottom ashes will depend on the obtained results. The kinetics of evaporation of $\mathrm{Cd}, \mathrm{Pb}, \mathrm{Cu}, \mathrm{Zn}$ from a MSW fly ash were 
determinated in different atmospheres between 670 and $1300{ }^{\circ} \mathrm{C}[14,15]$. Moreover, Sakai and Hiraoka [16] have investigated the distribution of metals between melted slag, gas cooler ash and bag filter ash obtained after direct melting of fly ashes at $1400{ }^{\circ} \mathrm{C}$. Finally, leaching characteristics of melted slag have been documented by Lin and Chang [17]. However, only few data are available concerning element behavior of MSW flue gas residues coupled with their mineralogy during thermal treatment. In this study, thanks to high-temperature experiments performed with MSW flue gas residues, we evaluate the range of their melting temperatures and their high-temperature phase relationships, together with the elemental behaviour between 150 and $1400^{\circ} \mathrm{C}$, especially for pollutant metals.

\section{Materials and methods}

\subsection{Experimental design}

This study principally focused on electrostatic precipitator (ESP) ash resulting from direct electrofiltration of flue gas. These solid residues were sampled in a MSW combustion facility located in an urban area of 600000 inhabitants in the southeast France, equipped with two parallel trains of 12 ton/h each. MSW is fed into the combustion chamber with a grate consisting of six rollers for each train. The ESP ashes were compared to another type of flue gas residues, a semi-dry scrubber residue (SDSR), obtained by semidry process, in which flue gas, after cooling, is cleaned by injection of a lime slurry into the scrubber. These SDSR residues come from a MSW combustion facility located in northeast France, equipped with two parallel trains, each having a nominal capacity rating of 6 ton/h, and a primary combustor with movable grates. The feed stream is composed of household waste collected from an area with 167000 inhabitants. ESP ashes and SDSR correspond to aluminosilicate materials, rich in calcium and chlorine, and containing numerous pollutants (As, Cd, Cr, Hg, Ni, Pb, Zn...) from tens of $\mu \mathrm{g} / \mathrm{g}$ to tens of thousands of $\mu \mathrm{g} / \mathrm{g}$. These 
residues consist of a very heterogeneous assemblage of glasses, metals, and crystals in which pollutant elements are distributed [5].

In order to determine the factors that control the behavior of pollutant elements in MSW combustors, and during the vitrification process, several types of experiments were performed using ESP ashes. We first defined their mean liquidus temperature and their liquidus phases (Table 1). In addition, during the heating of these residues, total mass loss was monitored by thermogravimetric experiments, changes in the mineralogy by X-ray diffraction and elemental behavior by chemical analyses. Finally, a set of experiments was carried out above the liquidus temperature, in order to document the evaporation rate of the main pollutants during vitrification of these ESP ashes.

\subsection{Raw material and sample preparation}

The chemistry and the mineralogy of several ESP ashes, sampled during two distinct periods in one combustion facility located in southeast France have been documented in a previous paper [5]. Since one of the main results of this study was to demonstrate the low seasonal chemical and mineralogical variations, one representative ESP ash of this sampling, noted ESP 261, have been chosen (Table 2). Two to three kilos of this sample were collected directly at the base of the electrostatic filter, prior to the storage silo. Then 50 grams were taken and quarted, in order to ensure sample homogeneity, and finally ground to a grain size less than $70 \mu \mathrm{m}$. The same protocole was used to sample one representative SDSR in a facility located in northeast France, where flue gas are treated by a semi-dry process.

\subsection{Experimental methods}

All experiments were performed at atmospheric pressure in a Gero vertical dropquench furnace, which can reach $1700{ }^{\circ} \mathrm{C}$. Temperature was controlled using a Eurotherm 
818 controller and measured by two independent $\mathrm{Pt}^{-\mathrm{PtRh}_{10}}$ thermocouples located in the hotspot of the furnace.

For the determination of the melting temperature, aliquots of 50-100 mg of powdery starting material were pressed onto wire platinum loops, with a diameter of $0.10 \mathrm{~mm}$, using polyvinyl alcohol as a binder. The sample was introduced into the center of the tube furnace, and directly heated at the dwell temperature. After each experiment and in order to frozen in the high temperature phase relations, the sample was drop-quenched in water at a quenching rates of the order of $500^{\circ} \mathrm{C} . \mathrm{s}^{-1}$. It was then mounted as polished sections for optical determination and/or electron-microprobe analyses.

The thermogravimetric analysis (TGA) measurements were carried out on a Sartorius LP220S, with a precision of $1 \mathrm{mg}$. For each TGA run, a platinum crucible filled with 2 grams of sample was heated with a constant heating rate of $25^{\circ} \mathrm{C}$ per hour from 100 ${ }^{\circ} \mathrm{C}$ to the final chosen temperature $\left(150^{\circ} \mathrm{C}, 400{ }^{\circ} \mathrm{C}, 650{ }^{\circ} \mathrm{C}, 1000{ }^{\circ} \mathrm{C}\right.$, and $\left.1300{ }^{\circ} \mathrm{C}\right)$, and held at this final temperature during one hour. At the end of TGA runs, samples were promptly removed from the furnace and stored in an oven to avoid any hydration from the ambient atmosphere. ICP-AES, ICP-MS and wet chemical methods were undertaken on these samples for bulk chemistry, while X-ray diffraction was used for mineralogical characterization.

For direct melting experiments, a platinum crucible was filled with 2 grams of sample, introduced into the center of the tube furnace, and directly heated from ambient (25 ${ }^{\circ} \mathrm{C}$ ) to the dwell temperature $\left(1400^{\circ} \mathrm{C}\right)$, during 1 hour and 16 hours respectively. At the end of each experiment, the sample was drop-quenched in water, and analyzed in the same way as TGA samples.

\subsection{Analytical methods}

For the determination of melting temperature and crystallization sequence, polished thin sections of quenched samples were examined using a CAMECA SX-50 electron 
microprobe equipped with 4 spectrometers and a wavelength-dispersive system (WDS), at the Université Henri Poincaré, Nancy 1. All WDS analyses were performed with a $15 \mathrm{kV}$ accelerating voltage and $10.0 \mathrm{nA}$ beam current. The following elements were analyzed: Na, Mg, Al, Si, P, S, Cl, K, Ca, Ti, Cr, Fe, Zn, and Pb. Electron microprobe standardization was conducted using polished geological standards prior to analyses. Incident-beam diameter was $10 \mu \mathrm{m}$ on glass to minimize the volatilization of alkalis, whereas a focused beam was used on crystalline phases.

For bulk chemistry performed at the Service d'Analyse des Roches et des Minéraux (SARM, CRPG-CNRS), major elements (Si, Al, Fe, Mn, Mg, Ca, Na, K, Ti and P) were analyzed by inductively coupled plasma atomic emission spectroscopy (ICP-AES), chlorine by absorptiometry, fluorine by potentiometry, sulfur and carbon by impulsion coulometry. Concentrations of trace pollutant elements (As to $\mathrm{Zn}$ ) were measured by inductively coupled plasma mass spectrometry (ICP-MS), except for mercury, analyzed by atomic absorption. Details of these chemical methods are given in a previous paper [5]. The relative uncertainties are 5 to $25 \%$ for contents around $1 \mu \mathrm{g} / \mathrm{g}, 2$ to $10 \%$ for contents in the order of $10 \mu \mathrm{g} / \mathrm{g}$, and 2 to $5 \%$ above $100 \mu \mathrm{g} / \mathrm{g}$.

For X-ray diffraction, a Jobin Yvon-Sigma 2080 diffractometer was used along with a copper X-ray source $(38 \mathrm{kV}, 20 \mathrm{~mA}, 800 \mathrm{~W})$ on sample powder $(<50 \mu \mathrm{m})$. Scans were conducted from 2 to $32^{\circ}$ at a rate of $0.5^{\circ}$ of $\theta$ per minute. The diffractogram was evaluated for possible crystalline phases using the ASTM (American Society for Testing Materials) data base for pure species.

\section{Results}

\subsection{Melting temperature and phase relations}

The liquidus temperature of ESP ashes was determined either by the reading of appropriate phase diagram and by melting experiments performed in high temperature 
furnace. Since ESP ashes are mainly constituted by $\mathrm{SiO}_{2}, \mathrm{CaO}, \mathrm{Al}_{2} \mathrm{O}_{3}$ and $\mathrm{Cl}$, with a total of around $75 \mathrm{wt} . \%,[3,5]$, and that chlorine is a highly volatile element, the melting products of fusion of ESP ashes can be properly represented in the ternary diagram $\mathrm{CaO}$ $\mathrm{SiO}_{2}-\mathrm{Al}_{2} \mathrm{O}_{3}$ [18]. All ESP ash compositions documented by Le Forestier and Libourel [5] were ploted in this diagram. These residues cluster in the same area, close to the gehleniteanorthite cotectic curve, which confirms their homogeneous composition in term of major elements (Fig. 1). The direct reading of this phase diagram allows us to estimate the melting temperatures of ESP ashes in the range $1265^{\circ} \mathrm{C}-1400{ }^{\circ} \mathrm{C}$.

These ESP ashes were compared to another type of flue gas residues, a semi-dry scrubber residue (SDSR), obtained by semi-dry process, in which flue gas, after cooling, is cleaned by injection of a lime slurry into the scrubber. In the same diagram (Fig. 1), SDSR samples are scattered toward the $\mathrm{CaO}$ end-member, in response to lime injection in the scrubber to neutralize acid gases. Accordingly, their melting temperature varies between $1900{ }^{\circ} \mathrm{C}$ and $2300{ }^{\circ} \mathrm{C}$, revealing the more refractory character of SDSR. Moreover, Fig. 1 shows that, despite the chemical and mineralogical discrepancies between SDSR and ESP ashes, their $\mathrm{SiO}_{2} / \mathrm{Al}_{2} \mathrm{O}_{3}$ ratio hardly varies outside 1.5 and 2.7. Assuming that these variations correspond to most of the flue gas residues, a temperature-composition section (T-X) can be drawn from this phase diagram to evaluate their liquidus temperature, simply as a function of their $\mathrm{CaO}$ content (Fig. 2).

In order to better constrain the melting temperatures of ESP ashes, a set of heating experiments was carried out on two different samples, for which experimental conditions are reported in Table 1. Experiments show that the liquidus temperature of ESP 261 and ESP 110 are in the range $1256-1272{ }^{\circ} \mathrm{C}$ and $1202-1256{ }^{\circ} \mathrm{C}$, respectively.

In addition, these experiments allow to characterize the phase relationships below the liquidus temperature. For ESP 261, electron microprobe analyses reveal that the liquidus phase is a spinel, belonging to the solid solution between spinel stricto sensu and Zn-rich aluminous spinel related to franklinite, containing an average of $7.24 \pm 0.39$ wt.\% 
of $\mathrm{Zn}, 2.34 \pm 0.29$ wt.\% of $\mathrm{Fe}$, and $0.88 \pm 0.47$ wt.\% of Cr. At $1225{ }^{\circ} \mathrm{C}$, anorthite $\left(\mathrm{CaAl}_{2} \mathrm{Si}_{2} \mathrm{O}_{8}\right)$ joins spinel as a crystallizing phase, followed by melilite $\left(\mathrm{Ca}_{2} \mathrm{Mg}_{0.26} \mathrm{Al}_{1.38} \mathrm{Si}_{1.53} \mathrm{O}_{7}\right)$ at $1190{ }^{\circ} \mathrm{C}$. Similar phase relationships were obtained for ESP 110.

\subsection{Mass losses}

Since solidification-stabilization processes may involve high temperature treatments, both chemical and mineralogical changes due to heating of ESP ash were investigated, using the coupling of thermogravimetric experiments, X-ray diffraction and chemical analyses.

Several thermogravimetric analyses (TGA) were performed on the representative ESP 261 sample between $100{ }^{\circ} \mathrm{C}$ and $1300{ }^{\circ} \mathrm{C}$ (Fig. 3), in order to characterize the associated mineralogical and chemical changes. The resulting thermogravimetric curves for final temperatures of $1300{ }^{\circ} \mathrm{C}, 1000{ }^{\circ} \mathrm{C}$ and $650{ }^{\circ} \mathrm{C}$ have the same shape, which confirms the reproductivity of mass loss, and indicate a total mass loss of around $18 \mathrm{wt} . \%$ at the final temperature of $1300{ }^{\circ} \mathrm{C}$. In details, the TGA curves show an initial rapid decrease between 100 and $150{ }^{\circ} \mathrm{C}$, followed by a less important mass loss in the range of 150 to $550{ }^{\circ} \mathrm{C}$. After a step with no mass loss between 550 and $800{ }^{\circ} \mathrm{C}$, we observe a significant decrease up to $1000{ }^{\circ} \mathrm{C}$. Above this temperature, the mass loss remains weak up to the melting temperature, suggesting that around $90 \%$ of the mass loss takes place before $1000{ }^{\circ} \mathrm{C}$ for this ESP ash.

X-ray diffractograms were carried out on the representative ESP 261 sample and on the by-products of each TGA experiments performed at $150{ }^{\circ} \mathrm{C}, 400{ }^{\circ} \mathrm{C}, 650{ }^{\circ} \mathrm{C}, 1000{ }^{\circ} \mathrm{C}$, and $1300{ }^{\circ} \mathrm{C}$, in order to relate these mass losses to mineralogical changes (Fig. 4). X-ray diffraction pattern reveals the occurrence of halite, sylvite, quartz, melilite, calcite, anhydrite, feldspar, and hematite in the selected ESP ash. However, our previous study devoted to the detailed characterization of MSW flue gas residues [5] has highlighted the 
more complex mineralogy of ESP ashes with the occurrence of other silicates, carbonates, chlorides, sulphates, oxides, and also graphite, hydroxides (e.g. portlandite), phosphates, and metallic phases (e.g. Al, Zn). As shown by X-ray diffraction, TGA products obtained at $150{ }^{\circ} \mathrm{C}$ and $400{ }^{\circ} \mathrm{C}$ contain the same major phases as the initial ESP ash (Fig. 4). At $650{ }^{\circ} \mathrm{C}$, corresponding to a relative mass loss of 11 wt.\%, the mineralogy is clearly different, with the disappearence of chlorides (sylvite and halite) and calcite, and the crystallization of mayenite $\left(\mathrm{Ca}_{12} \mathrm{Al}_{14} \mathrm{O}_{33}\right)$. At $1000{ }^{\circ} \mathrm{C}$, mayenite and anhydrite no longer exist, whereas the intensity of peaks for melilite and wollastonite $\left(\mathrm{CaSiO}_{3}\right)$ increases. Finally, all peaks of diffraction disappear in favour of amorphous bump at $1300{ }^{\circ} \mathrm{C}$, which confirms the melting of ESP ashes in this temperature range (Fig. 1 and 2).

In addition, after TGA, all samples were analyzed by ICP-AES and ICP-MS, analytical results are reported in Table 2. By comparison with non-heated samples, these results reveal that, as expected, refractory elements concentrate in the most heated samples, while the reverse trend is observed for the volatile elements. For instance, $\mathrm{Al}, \mathrm{Ca}$ and $\mathrm{Ti}$ contents increase with temperature, whereas $\mathrm{Cl}$, S, Na, and $\mathrm{K}$ contents decline. Amongst the pollutant elements, $\mathrm{Hg}, \mathrm{Cd}, \mathrm{Pb}$, and $\mathrm{Cu}$ are strongly depleted, whereas $\mathrm{As}, \mathrm{Co}, \mathrm{Cr}, \mathrm{Ni}$, Sb, Sn, and Zn remain in the residues.

Since the glass resulting from TGA experiment at $1300{ }^{\circ} \mathrm{C}$ was obtained after 48 hours of heating, additional melting experiments were performed on the same starting ESP 261 composition, in order to better simulate the vitrification occuring at an industrial scale. Experiments were carried out for 1 and 16 hours by direct melting of the sample at $1400{ }^{\circ} \mathrm{C}$ in air (Table 2). All experiments produced calcium-rich aluminosilicate glasses. Both calculated and measured mass losses are in good agreement, 19 wt.\% for melting during TGA experiment at $1300{ }^{\circ} \mathrm{C}$, and $\sim 22$ wt.\% for direct melting at $1400{ }^{\circ} \mathrm{C}$ for 1 and 16 hours. These results show that, by comparison with the initial composition, the main changes of composition occur during the first hour, in accordance with the work of Jakob et al. [14] on similar flue gas residues. 


\section{Discussion}

\subsection{High temperature behavior of ESP ash}

The relative amount of evaporation of elements can be calculated from the mass loss and the chemical composition, using the following expression:

$$
\mathrm{E}_{\mathrm{i}, \mathrm{T}}=100 \cdot\left[1-\left(\mathrm{m}_{\mathrm{T}} / \mathrm{m}_{0}\right) \cdot\left(\mathrm{X}_{\mathrm{i}, \mathrm{T}} / \mathrm{X}_{\mathrm{i}, 0}\right)\right]
$$

where $E_{i, T}$ is the relative amount of evaporation of the element $i$ at temperature $T, m_{T}$ is the final mass measured at $T, m_{0}$ is the initial mass (2 grams), $X_{i, T}$ is the content of $i$ in the product obtained after TGA up to $\mathrm{T}$, and $\mathrm{X}_{\mathrm{i}, 0}$ is the content of $\mathrm{i}$ in the initial ESP ash. Chemical analyses of the initial ESP ash and of each TGA product are given in Table 2, whereas relative amount of evaporation for major volatile elements as a function of temperature is represented in Fig. 5.

All together, these results allow to depict the high temperature behavior of these ESP ashes, in term of their mineralogy and chemistry. After the evaporation of $2.1 \mathrm{wt} . \%$ water before $150{ }^{\circ} \mathrm{C}$, organic carbon has been oxidized to $\mathrm{CO}_{2}$ and almost totally volatilized at $400{ }^{\circ} \mathrm{C}$. The remaining carbon, given by difference between total carbon and organic carbon, is related to carbonates. According to Fig. 5a, this inorganic carbon is volatilized at $650{ }^{\circ} \mathrm{C}$, due to the disappearence of calcite by decarbonatation, as shown by X-ray diffractograms in Fig. 4. Similarly, the disappearence of chlorides (halite and sylvite) around $650{ }^{\circ} \mathrm{C}$ is supported by the similar behavior of alkali elements ( $\mathrm{Na}$ and $\mathrm{K}$ ) and chlorine, with a significant increase of their evaporation rate between 400 and $1000{ }^{\circ} \mathrm{C}$. In the same temperature range, a calcium aluminate, i.e. mayenite $\left(\mathrm{Ca}_{12} \mathrm{Al}_{14} \mathrm{O}_{33}\right)$ formed (Fig. 4), very likely in response to the deshydration of portlandite or the decalcification of $\mathrm{CaO}-\mathrm{SiO}_{2}-$ $\mathrm{H}_{2} \mathrm{O}(\mathrm{CSH})$ phases and the oxidation of metallic aluminum. At $1000{ }^{\circ} \mathrm{C}$, the mineralogy is dominated by melilite, quartz, feldspar and wollastonite. Raising the temperature up to $1000^{\circ} \mathrm{C}$ led to the development of wollastonite and melilite. This is in agreement with the 
findings of Karoly et al. [19] who conducted heat treatment of MSW fly ashes at temperatures between 850 and $1050^{\circ} \mathrm{C}$, however, using a previous melting at $1600^{\circ} \mathrm{C}$ followed by a cooling and annealing at $600^{\circ} \mathrm{C}$. As shown in Fig. 5a, sulfur shows a constrasting behavior, by comparison with chlorine, and mainly vaporizes between 1000 and $1300{ }^{\circ} \mathrm{C}$. After direct melting at $1190{ }^{\circ} \mathrm{C}$ of ESP ash, the main crystalline phases were identified as spinel, anorthite, and melilite. These parageneses, obtained at $1000{ }^{\circ} \mathrm{C}$ and $1190{ }^{\circ} \mathrm{C}$, are in agreement with phase relationships at the eutectic point $\left(1170{ }^{\circ} \mathrm{C}\right)$ in the ternary diagram $\mathrm{CaO}-\mathrm{SiO}_{2}-\mathrm{Al}_{2} \mathrm{O}_{3}$ (Fig. 1). Clozel and Legendre [20] have characterized the paragenesis of MSW flue gas residues heated at around $1200{ }^{\circ} \mathrm{C}$. They have identified similar phases (spinel stricto sensu, melilite close to gehlenite, plagioclase), but also Ca rich-pyroxene and some minor phases such as apatite and perovskite. Moreover, our melting temperatures are in good agreement with Lin and Chang [17] for the melting of a cyclone ash $\left(1250^{\circ} \mathrm{C}\right)$, and a little above to those given by Jakob et al. [14] for MSWC fly ashes $\left(1180{ }^{\circ} \mathrm{C}\right)$, because of higher amounts of refractory elements (Ca, $\left.\mathrm{Al}, \mathrm{Mg}\right)$ in our selected ESP ash.

The predicted liquidus temperatures, obtained by using the ternary diagram $\mathrm{CaO}$ $\mathrm{SiO}_{2}-\mathrm{Al}_{2} \mathrm{O}_{3}$, are in the same order of magnitude as the experimental ones, but a little higher. The small difference may be simply explained by the presence of minor elements which act as fluxes (e.g. Fe, Na, K, P). Therefore, predicted liquidus temperature based on the $\mathrm{CaO}-$ $\mathrm{SiO}_{2}-\mathrm{Al}_{2} \mathrm{O}_{3}$ ternary diagram represents an upper limit for the melting of ESP ashes.

\subsection{Specific behavior of pollutants}

Concerning pollutant elements (Fig. 5b), all mercury has already volatilized at 400 ${ }^{\circ} \mathrm{C}$. Metallic mercury $\mathrm{Hg}^{0}$ has very low boiling point, at $357^{\circ} \mathrm{C}$ [21], and according to Galbreath and Zygarlicke [22], $\mathrm{Hg}^{0}(\mathrm{~g})$ is the thermodynamically stable form in the highest temperature regions of combustors. However, the high chlorine partial pressure prevailing during waste combustion may cause the oxidation of mercury, and chloride mercury 
species may be the major form in the cooling process of flue gas, as shown by Ghorishi et al. [23], Chen et al. [24]. Lead, cadmium and copper show similar evaporation curves, with the principal volatilization between 650 and $1000{ }^{\circ} \mathrm{C}$. For fine-grained fly ash, Jakob et al. [14] have found that more than $90 \%$ of evaporation in air is obtained from $670{ }^{\circ} \mathrm{C}$ for $\mathrm{Pb}$, $750{ }^{\circ} \mathrm{C}$ for $\mathrm{Cd}$, and $850{ }^{\circ} \mathrm{C}$ for $\mathrm{Cu}$. Considering the boiling points of $\mathrm{Pb}, \mathrm{Cd}$ and $\mathrm{Cu}$ and their compounds (e.g. oxides, chlorides, sulphates) [21], we can deduce that (i) none of the oxides is volatile below $1000{ }^{\circ} \mathrm{C}$, (ii) $\mathrm{Pb}$ and $\mathrm{Cu}$ metals are refractory, whereas $\mathrm{Cd}$ metal is volatile at $765{ }^{\circ} \mathrm{C}$, (iii) sulphates of $\mathrm{Cd}$ and $\mathrm{Pb}$ are not volatile, and $\mathrm{CuSO}_{4}$ is decomposed in $\mathrm{CuO}$, (iv) chlorides of $\mathrm{Pb}, \mathrm{Cd}$ and $\mathrm{Cu}$ are volatile below $1000{ }^{\circ} \mathrm{C}$. As the high chlorine content in ESP ash will create an important partial pressure of chlorine during heating, chloride is the most probable form of evaporation for $\mathrm{Pb}, \mathrm{Cd}$ and $\mathrm{Cu}$. Fig. 5b shows a lesser evaporation for copper at high temperature, which can be explained by the occurence of metallic alloys in addition with chloride copper.

For zinc, the relative amount of evaporation raises with increasing temperature from $0 \%$ at $650{ }^{\circ} \mathrm{C}, 20 \%$ at $1000{ }^{\circ} \mathrm{C}$, and $1300{ }^{\circ} \mathrm{C}$ (Fig. 5b). The direct melting at $1400{ }^{\circ} \mathrm{C}$ during one hour reveals an evaporation of zinc at around $60 \%$ (Table 2). Incomplete evaporation is found for zinc in air. That is in accordance with the crystallization of spinel, the stable phase at the liquidus, which contains more than $7 \%$ of zinc. Jakob et al. [14] found also an increasing evaporation of zinc, up to $51 \%$ at $1030{ }^{\circ} \mathrm{C}$, but followed by a decrease to as low as $14 \%$ at temperatures above the melting range of the filter ash. According to these authors, zinc exists in the form of oxide in the initial filter ash, and heating in air creates a competition between the formation of volatile zinc chloride and the formation of stable zinc silicate and zinc spinel. Struis et al. [25] have detailed the quantitative $\mathrm{Zn}$ speciation at different heat treatment stages, under $\mathrm{Ar}$ or $\mathrm{Ar}+\mathrm{O}_{2}$ carrier gas. Under $\mathrm{O}_{2}$-enriched carrier gas, the $\mathrm{Zn}$-bearing species of fly ash samples collected at different temperatures $\left(400{ }^{\circ} \mathrm{C}, 765{ }^{\circ} \mathrm{C}\right.$ and $910{ }^{\circ} \mathrm{C}$ ) were identified as $\mathrm{Zn}_{2} \mathrm{SiO}_{4}, \mathrm{ZnAl}_{2} \mathrm{O}_{4}$, $\mathrm{Zn}_{5}(\mathrm{OH})_{5}\left(\mathrm{CO}_{3}\right)_{2}$, and $\mathrm{ZnO}$. We suggest a complex crystal-chemistry of zinc in the initial 
ESP ash, as shown by a previous study [5]: zinc was found as pure metallic particles, spinels, alloys, and Ca-bearing aluminosilicate glasses. It is noticeable that particles of zinc metal and alloys can have been partially oxidized during heating in air. So, the increase of evaporation of zinc is due to the different Zn-bearing species, which are very volatile (e.g. zinc metal) as well as refractory (e.g. spinel).

The other potentially toxic metals reveal a different behavior during heating, even if uncertainties of the calculated amounts of evaporation are higher due to the low contents of these metals in the fly ash residues. Chromium presents a negligible evaporation (Fig. 5b), and a similar trend was obtained for nickel, antimony and tin. No evidence was found concerning their main bearing phases, with the notable exception of $\mathrm{Ni}$, for which spinel and metallic alloys were identified as potential Ni carrier.

\section{Conclusions}

The results presented in this study can be thus used as a guide for vitrification processes, especially for industrial furnace control. So, in industrial glassmaking furnaces using typically temperatures around $1400{ }^{\circ} \mathrm{C}$, the direct vitrification of ESP ash is possible without any additives, because the silica content is enough to form a glass. On the contrary, semi-dry scrubber residues are more refractory with high amounts of calcium, and additives, such as $\mathrm{Na}_{2} \mathrm{CO}_{3}$ or $\mathrm{SiO}_{2}$, are necessary to melt these residues at lower temperatures than their melting one [26].

In addition to previous studies, our knowledge of polluting element behavior of MSW flue gas residues at high temperature has been significantly improved, leading to two different strategies for the management of MSW flue gas residues. In the first one, the objective is to promote the efficiency of the transfer of pollutant elements to the raw gas, in order to obtain vitrified products containing low amounts of toxic elements. In this case, these vitrified products, often called slags, may be used as secondary raw materials, such as 
subbase in road construction or supplement for pavement. However and as shown in this paper, fumes obtained after vitrification concentrated the more toxic and volatile elements, which may create hazardous aerosols during condensation. In order to avoid such a transfer of pollution from the solid by-product of the incineration to the gas, fumes have therefore to be treated before their release in the atmosphere. In this alternative strategy, the challenge is to remove the soluble metals (e.g. $\mathrm{Hg}, \mathrm{Cd}, \mathrm{Pb}$ ) from the MSW flue gas residues by an efficient leaching before vitrification, and to retain in an irreversible manner most of the remaining polluting elements in the vitrified products, either in the glassy matrix or better in stable crystalline phases, like spinels for $\mathrm{Cr}$, Ni, Zn. Since during storage or reuse of these vitrified products the risk of release of toxic metals in the environment remains a threat, it is clear that their long-term durability has to be investigated, as well.

\section{Acknowledgements}

Thanks are expressed to SARM (CRPG-CNRS, Nancy) for chemical analyses, François Lhôte (LEM, Nancy) for XRD, Sandrine Mathieu (Université Henri Poincaré, Nancy 1) for electron microprobe analyses. We also thank two anonymous reviewers for the constructive reviews that helped improve the clarity of the manuscript. This study was financially supported by the SITA group. Finally, the authors thank David Avery for English editing. This is a ISTO contribution $n^{\circ}$ YYYY and CRPG contribution $n^{\circ} \mathrm{XXXX}$.

\section{References}

[1] R.R. Greenberg, W.H. Zoller, G.E. Gordon, Composition and size distributions of particles released in refuse incineration, Environ. Sci. Technol. 12 (1978) 566-573.

[2] J.L. Ontiveros, T.L. Clapp, D.S. Kosson, Physical properties and chemical species distributions within municipal waste combuster ashes, Environ. Prog. 8 (1989) 200206. 
[3] A. Plüss, R.E. Ferrell, Characterization of lead and other heavy metals in fly ash from municipal waste incinerators, Hazard. Waste Hazard. Mater. 8 (1991) 275-292.

[4] A. Goldin, C. Bigelow, P.L.M. Veneman, Concentrations of metals in ash from municipal solid waste combusters, Chemosphere 24 (1992) 271-280.

[5] L. Le Forestier, G. Libourel, Characterization of flue gas residues from municipal solid waste combustors, Environ. Sci. Technol. 32 (1998) 2250-2256.

[6] J. Carignan, G. Libourel, C. Cloquet, L. Le Forestier, Lead isotopic composition of fly ash and flue gas residues from municipal solid waste combustors in France: implications for atmospheric lead source tracing, Environ. Sci. Technol. 39 (2005) 2018-2024.

[7] C.A. Cahill, L.W. Newland, Comparative efficiencies of trace metal extraction from municipal incinerator ashes, Intern. J. Environ. Anal. Chem. 11 (1982) 227-239.

[8] I.A. Legiec, C.A. Hayes, D.S. Kosson, Continuous recovery of heavy metals from MSW incinerator ashes, Environ. Prog. 8 (1989) 212-217.

[9] S. Cernushi, M. Giugliano, I. de Paoli, Leaching of residues from MSW incineration, Waste Management \& Research 8 (1990) 419-427.

[10] S.S. Krishnan, R.E. Jervis, L.D. Vela, Leachability of toxic elements from solid wastes, Journal of Radioanalytical and Nuclear Chemistry 161 (1992) 181-187.

[11] C.S. Kirby, J.D. Rimstidt, Interaction of municipal solid waste ash with water, Environ. Sci. Technol. 28 (1994) 443-451.

[12] T.T. Eighmy, J.D. Eusden, J.E. Krzanowski, D.S. Domingo, D. Stämpfli, J.R. Martin, P.M. Erickson, Comprehensive approach toward understanding element speciation and leaching behavior in municipal solid waste incineration electrostatic precipitator ash, Environ. Sci. Technol. 29 (1995) 629-646.

[13] P.P. Bosshard, R. Bachofen, H. Brandl, Metal leaching of fly ash from municipal waste incineration by Aspergillus niger, Environ. Sci. Technol. 30 (1996) 30663070. 
[14] A. Jakob, S. Stucki, P. Kuhn, Evaporation of heavy metals during the heat treatment of municipal solid waste incinerator fly ash, Environ. Sci. Technol. 29 (1995) 24292436.

[15] A. Jakob, S. Stucki, R.P.W.J. Struis, Complete heavy metal removal from fly ash by heat treatment: influence of chlorides on evaporation rates, Environ. Sci. Technol. 30 (1996) 3275-3283.

[16] S.I. Sakai, M. Hiraoka, Municipal solid waste incinerator residue recycling by thermal processes, Waste Manage. 20 (2000) 249-258.

[17] K.L. Lin, C.T. Chang, Leaching characteristics of slag from the melting treatment of municipal solid waste incinerator ash, J. Hazard. Mater. B135 (2006) 296-302.

[18] E.M. Levin, C.R. Robbins, H.F. Mc Murdie, Phase Diagrams for Ceramists, third ed., American Ceramics Society, Columbus, Ohio, 1964.

[19] Z. Karoly, I. Mohai, M. Toth, F. Weber, J. Szepvölgyi, Production of glass-ceramics from fly ash using arc plasma, J. Eur. Ceram. Soc. 27 (2007) 1721-1725.

[20] B. Clozel, O. Legendre, Caractérisation minéralogique et cristallochimique de vitrifiats, Proceedings of the International Congress on Waste SolidificationStabilisation Processes, 28 november-1st december 1995, Nancy, France, 1997, pp. 53-57.

[21] R.C. Weast, M.J. Astle, W.H. Beyer, Handbook of Chemistry and Physics, 69th ed., CRC Press, Boca Raton, Florida, 1988-1989.

[22] K.C. Galbreath, C.J. Zygarlicke, Mercury speciation in coal combustion and gasification flue gases, Environ. Sci. Technol. 30 (1996) 2421-2426.

[23] S.B. Ghorishi, C.W. Lee, W.S. Jozewicz, J.D. Kilgroe, Effects of fly ash transition metal content and flue gas $\mathrm{HCl} / \mathrm{SO}_{2}$ ratio on mercury speciation in waste combustion, Environ. Eng. Sci. 22 (2005) 221-231. 
[24] L. Chen, Y. Zhuo, X. Zhao, Q. Yao, L. Zhang, Thermodynamic comprehension of the effect of basic ash compositions on gaseous mercury transformation, Energ. Fuel 21 (2007) 501-505.

[25] R.P.W.J. Struis, C. Ludwig, H. Lutz, A.M. Scheidegger, Speciation of zinc in municipal solid waste incineration fly ash after heat treatment: an X-ray absorption spectroscopy study, Environ. Sci. Technol. 38 (2004) 3760-3767.

[26] Y.J. Park, J. Heo, Vitrification of fly ash from municipal solid waste incinerator, J. Hazard. Mater. B91 (2002) 83-93.

[27] R. Kretz, Symbols for rock-forming minerals, Am. Mineral. 68 (1983) 277-279. 
Fig. 1. Liquidus surface, sub-solidus equilibria, and location of the electrostatic precipitator (ESP) ash and semi-wet scrubber residues (SDSR) samples in the $\mathrm{CaO}-\mathrm{SiO}_{2}-\mathrm{Al}_{2} \mathrm{O}_{3}$ system [18].

Fig. 2. Diagram showing the theoritical and experimental liquidus temperature of flue gas residues as a function of their $\mathrm{CaO}$ content, for two $\mathrm{SiO}_{2} / \mathrm{Al}_{2} \mathrm{O}_{3}$ ratios, 1.5 and 2.7 respectively. This diagram corresponds to sections through the phase diagram in the $\mathrm{CaO}$ $\mathrm{SiO}_{2}-\mathrm{Al}_{2} \mathrm{O}_{3}$ system.

Fig. 3. Weight loss curves obtained by thermogravimetric analysis (TGA) of the selected electrostatic precipitator ash ESP 261. TGA 1300, TGA 1000 and TGA 650 correspond to thermogravimetric curves for final temperatures of 1300,1000 , and $650{ }^{\circ} \mathrm{C}$, respectively. TGA, thermogravimetric analysis.

Fig. 4. X-ray diffraction patterns of the selected electrostatic precipitator ash ESP 261, and of run products obtained after thermogravimetric analysis (TGA) measuments. TGA 150, TGA 400, TGA 650, and TGA 1000 correspond to run products obtained after TGA for final temperatures of 150,400 , and $1000{ }^{\circ} \mathrm{C}$, respectively. TGA, thermogravimetric analysis; $\mathrm{Hl}=$ halite; Syl = sylvite; $\mathrm{Qtz}=$ quartz; Cal = calcite; Anh = anhydrite; Mel = melilite; Fs = feldspar; Hem = hematite; May = mayenite; Wo = wollastonite. Symbols used for synthetic solid phases related to minerals are those of Kretz [27].

Fig. 5. Relative amount of evaporation as a function of temperature, (a) of the volatile elements $\mathrm{Na}, \mathrm{K}, \mathrm{Rb}, \mathrm{Cs}, \mathrm{Cl}, \mathrm{S}, \mathrm{C}$, TOC (total organic carbon), and (b) of the pollutant elements $\mathrm{Hg}, \mathrm{Cd}, \mathrm{Pb}, \mathrm{Cu}, \mathrm{Zn}, \mathrm{Cr}$, for the selected electrostatic precipitator ash ESP 261. The heat treatment of this ESP ash, performed in air, consists of thermogravimetric 
measurements for $150,400,650,1000$, and $1300{ }^{\circ} \mathrm{C}$, and direct melting for 1350,1400 , and $1500^{\circ} \mathrm{C}$. 
Table 1. Phases relationship experimental conditions for two representative fly ashes

\begin{tabular}{|c|c|c|c|c|}
\hline Run & Raw material & $\begin{array}{l}\text { Duration } \\
\text { (hours) } \\
\end{array}$ & $\begin{array}{c}\text { Temperature } \\
\left({ }^{\circ} \mathrm{C}\right) \\
\end{array}$ & Phases present in the sample \\
\hline CEL2 & ESP 261 & 4 & 1350 & Glass \\
\hline CEL1 & ESP 261 & 1 & 1290 & Glass \\
\hline CEL8 & ESP 261 & 1 & 1272 & Glass \\
\hline CEL9 & ESP 261 & 1 & 1256 & Glass $+\mathrm{Spl}^{\mathrm{a}}$ \\
\hline CEL5 & ESP 261 & 24 & 1240 & Glass + Spl \\
\hline CEL10 & ESP 261 & 1 & 1225 & Glass + Spl $+\mathrm{An}^{\mathrm{b}}$ \\
\hline CEL7 & ESP 261 & 24 & 1190 & Glass $+\mathrm{Spl}+\mathrm{An}+\mathrm{Mel}^{\mathrm{C}}$ \\
\hline CEL8 & ESP 110 & 1 & 1272 & Glass \\
\hline CEL9 & ESP 110 & 1 & 1256 & Glass \\
\hline CEL11 & ESP 110 & 1 & 1202 & Glass + Spl + An + Mel \\
\hline
\end{tabular}

${ }^{\mathrm{a}} \mathrm{Spl}=$ spinel $\left(\mathrm{Mg}_{0.82} \mathrm{Zn}_{0.18}\right)\left(\mathrm{Al}_{1.91} \mathrm{Fe}_{0.06} \mathrm{Cr}_{0.03}\right) 0_{4} .{ }^{\mathrm{b}} \mathrm{An}=$ anorthite $\mathrm{CaAl}_{2} \mathrm{Si}_{2} \mathrm{O}_{8} .{ }^{\mathrm{c}} \mathrm{Mel}=$ melilite $\mathrm{Ca}_{2} \mathrm{Mg}_{0.26} \mathrm{Al}_{1.38} \mathrm{Si}_{1.53} \mathrm{O}_{7}$. 
Table 2. Chemical composition of the selected electrostatic precipitator ash, ESP 261, of the products TGAi obtained by heating ESP 261 up to $i{ }^{\circ} \mathrm{C}$, and of the glasses, DM 1h 1400 and DM 16h 1400, obtained after direct melting of ESP 261 at $1400{ }^{\circ} \mathrm{C}$ during 1 and 16 hours, respectively.

\begin{tabular}{|c|c|c|c|c|c|c|c|c|}
\hline & ESP 261 & $\begin{array}{c}\text { TGA }^{\mathrm{a}} \\
150 \\
\end{array}$ & $\begin{array}{c}\text { TGA } \\
400\end{array}$ & $\begin{array}{c}\text { TGA } \\
650\end{array}$ & $\begin{array}{l}\text { TGA } \\
1000\end{array}$ & $\begin{array}{l}\text { TGA } \\
1300 \\
\end{array}$ & $\begin{array}{c}\text { DM 1h } \\
1400\end{array}$ & $\begin{array}{c}\text { DM 16h } \\
1400\end{array}$ \\
\hline Mass $^{\mathrm{b}}$ (mg) & 2000 & 1958 & 1915 & 1830 & 1690 & 1643 & & \\
\hline Mass $\operatorname{loss}^{c}(\%)$ & & 2.10 & 4.25 & 8.50 & 15.50 & $17.8519^{\mathrm{d}}$ & 22 & 22 \\
\hline Si (wt.\%) & 13.57 & 13.75 & 14.34 & 15.77 & 16.78 & 16.78 & 17.36 & 17.14 \\
\hline $\mathrm{Al}$ (wt.\%) & 8.85 & 8.98 & 9.40 & 10.47 & 11.20 & 11.32 & 12.22 & 12.27 \\
\hline Fe (wt.\%) & 1.20 & 1.22 & 1.38 & 1.21 & 1.31 & 1.33 & 0.67 & 0.91 \\
\hline Mn (wt.\%) & 0.08 & 0.09 & 0.09 & 0.09 & 0.10 & 0.11 & 0.08 & 0.08 \\
\hline Mg (wt.\%) & 1.78 & 1.83 & 1.89 & 2.18 & 2.22 & 2.22 & 2.30 & 2.22 \\
\hline Ca (wt.\%) & 15.94 & 16.14 & 16.52 & 18.07 & 18.88 & 19.95 & 20.48 & 20.31 \\
\hline Na (wt.\%) & 2.40 & 2.46 & 2.18 & 1.73 & 1.70 & 1.09 & 1.26 & 1.05 \\
\hline K (wt.\%) & 3.35 & 3.35 & 3.01 & 2.20 & 1.15 & 0.58 & 0.37 & 0.29 \\
\hline Ti (wt.\%) & 1.00 & 1.02 & 1.06 & 1.14 & 1.25 & 1.24 & 1.22 & 1.22 \\
\hline P (wt.\%) & 0.55 & 0.50 & 0.59 & 0.61 & 0.68 & 0.66 & 0.61 & 0.63 \\
\hline $\mathrm{LOI}^{\mathrm{e}}$ (wt.\%) & 16.93 & 15.85 & 13.51 & 7.38 & 2.38 & 0.15 & n.d. & n.d. \\
\hline Cl (wt.\%) & 6.58 & 6.50 & 5.37 & 3.81 & 0.70 & 0.01 & 0 & 0 \\
\hline S (wt.\%) & 0.90 & 0.85 & 0.97 & 0.94 & 0.75 & 0.02 & 0 & 0 \\
\hline total C (wt.\%) & 3.08 & 3.28 & 1.04 & 0.15 & 0.04 & n.d. & n.d. & n.d. \\
\hline TOC $^{f}$ (wt.\%) & 2.63 & 2.73 & 0.25 & n.d. ${ }^{\mathrm{g}}$ & n.d. & n.d. & n.d. & n.d. \\
\hline As (ppm) & 18 & 19 & 19 & 21 & 22 & 22 & 14 & 6 \\
\hline Cd (ppm) & 115 & 117 & 118 & 116 & 11 & 6 & 7 & 3 \\
\hline Co (ppm) & 16 & 18 & 18 & 19 & 21 & 21 & 14 & 15 \\
\hline Cr (ppm) & 371 & 373 & 397 & 364 & 448 & 425 & 304 & 148 \\
\hline $\mathrm{Cu}(\mathrm{ppm})$ & 792 & 790 & 800 & 854 & 265 & 84 & 97 & 71 \\
\hline Hg (ppm) & 14 & 14.4 & 0.6 & n.d. & n.d. & n.d. & n.d. & n.d. \\
\hline $\mathrm{Ni}(\mathrm{ppm})$ & 67 & 68 & 71 & 62 & 74 & 74 & 30 & 28 \\
\hline $\mathrm{Pb}(\mathrm{ppm})$ & 1914 & 2246 & 2286 & 1503 & 225 & 128 & 645 & 240 \\
\hline $\mathrm{Sb}(\mathrm{ppm})$ & 284 & 302 & 302 & 317 & 317 & 333 & 240 & 211 \\
\hline Sn (ppm) & 787 & 802 & 805 & 835 & 830 & 889 & 708 & 915 \\
\hline
\end{tabular}


${ }^{a}$ TGA, thermogravimetric analysis. ${ }^{b}$ This mass corresponds to the initial mass for ESP and to the final mass obtained after each TGA. ${ }^{\mathrm{c}}$ Mass loss $=100$.(initial mass - final mass) / initial mass. ${ }^{\mathrm{d}}$ In italic, the calculated mass loss $(\%)=100$. [1 $\left.-\left(\mathrm{X}_{\mathrm{Si}, \mathrm{ESP} \text { ash }} / \mathrm{X}_{\mathrm{Si}, \mathrm{Glass}}\right)\right]$. ${ }^{\mathrm{e}} \mathrm{LOI}=$ loss on ignition at $980{ }^{\circ} \mathrm{C} .{ }^{\mathrm{f}} \mathrm{TOC}=$ total organic carbon. ${ }^{\mathrm{g}}$ n.d. $=$ not determined . 
Fig. 1

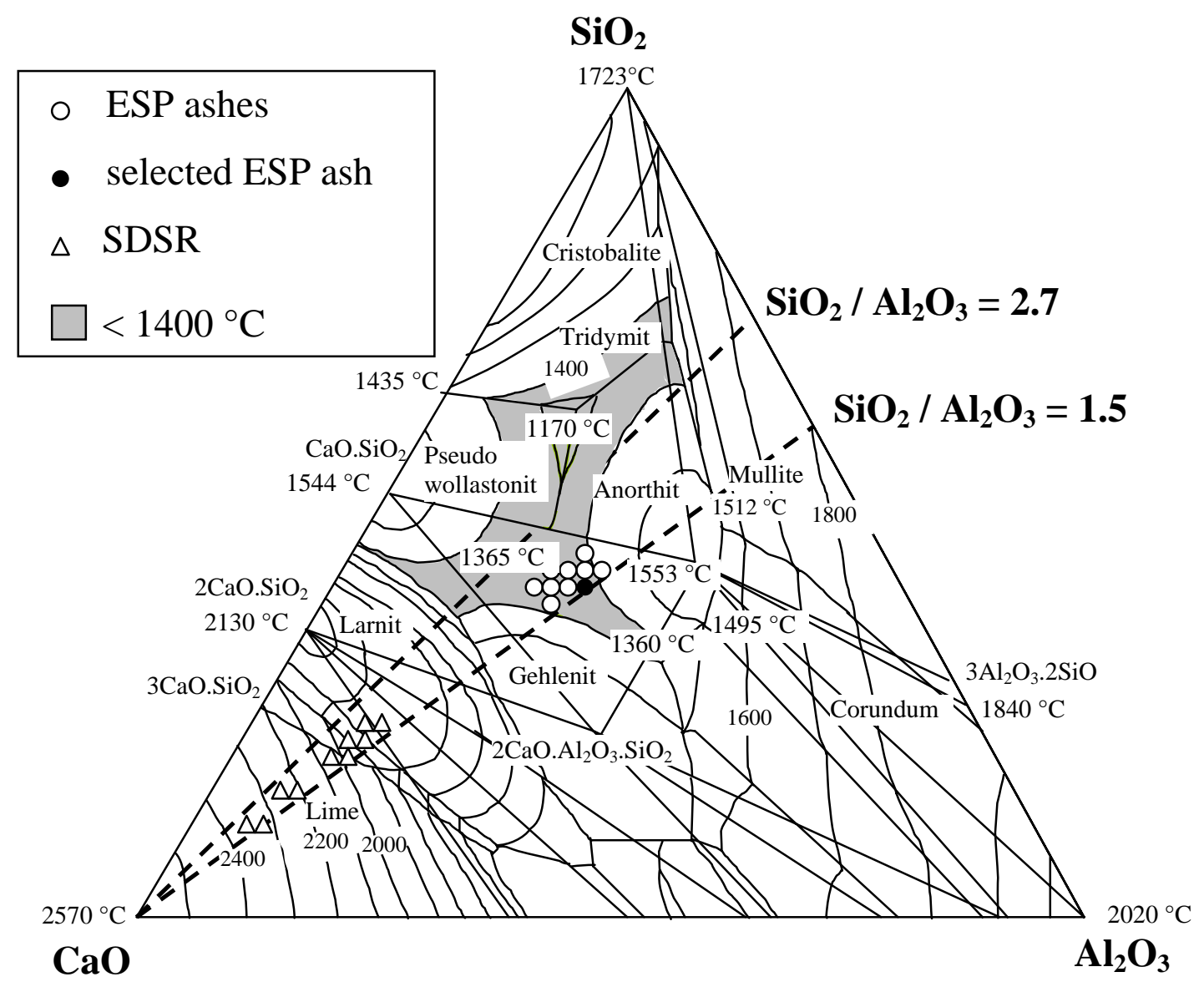


Fig. 2

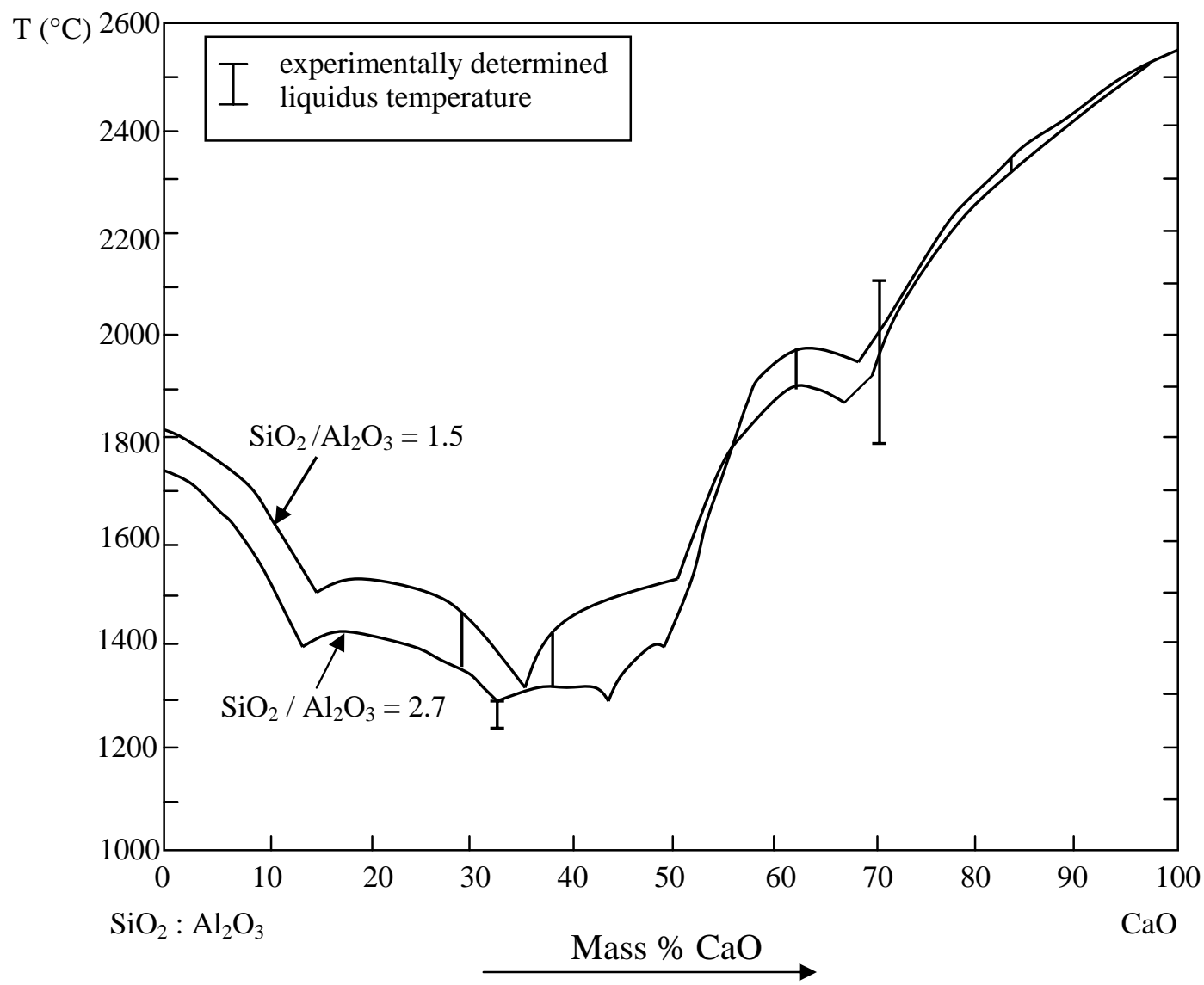


Fig. 3

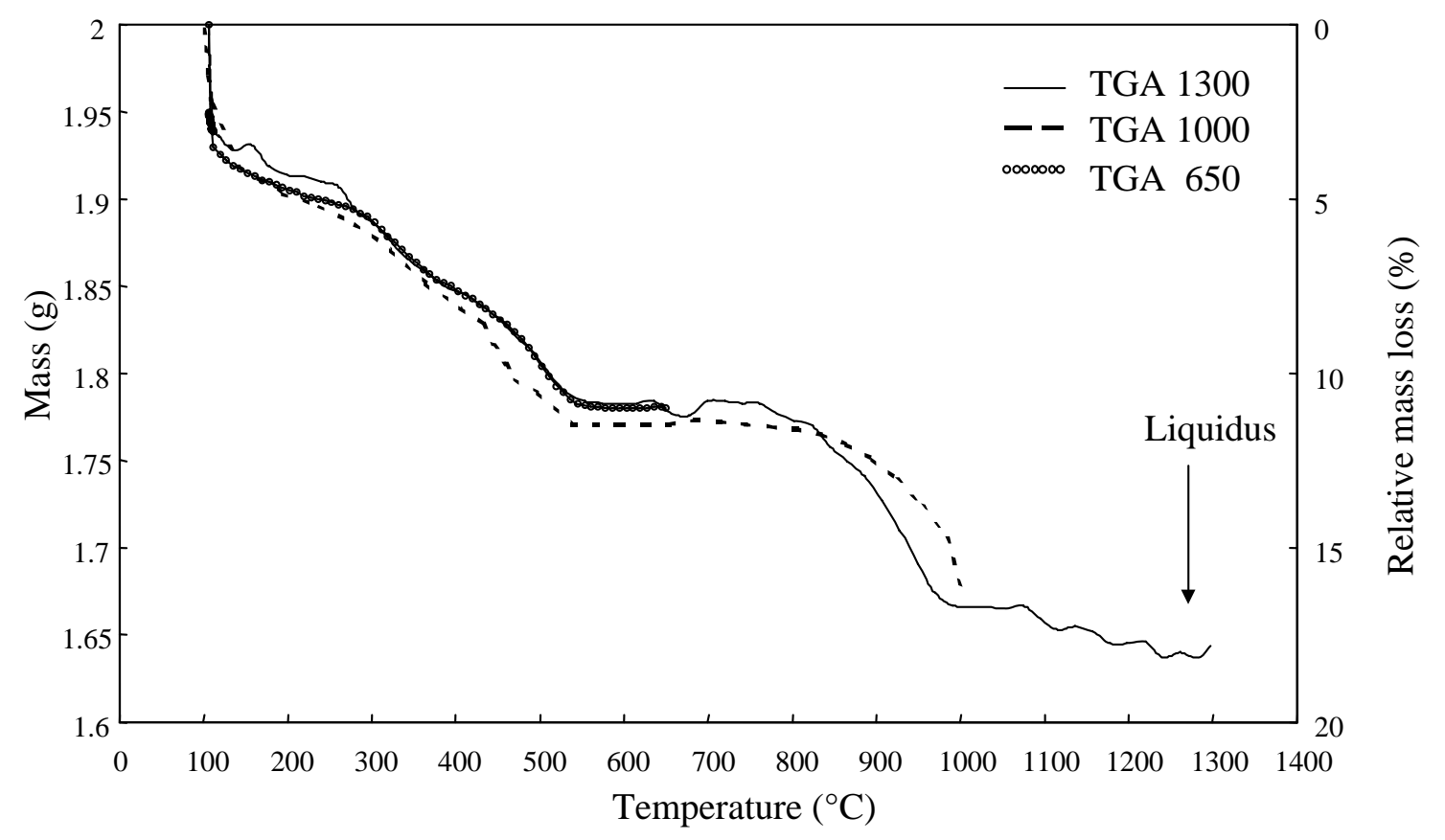


Fig. 4

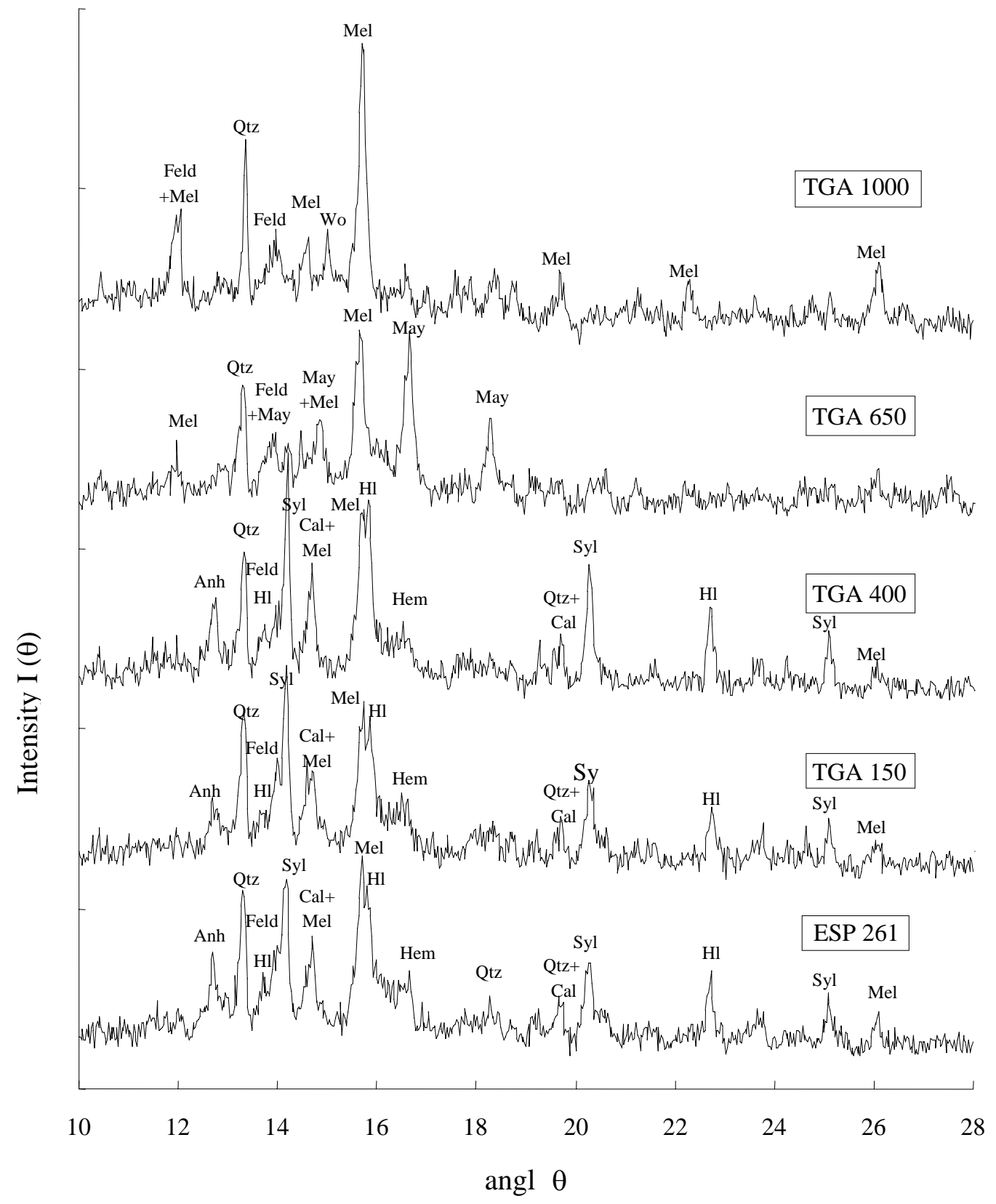


Fig. 5a

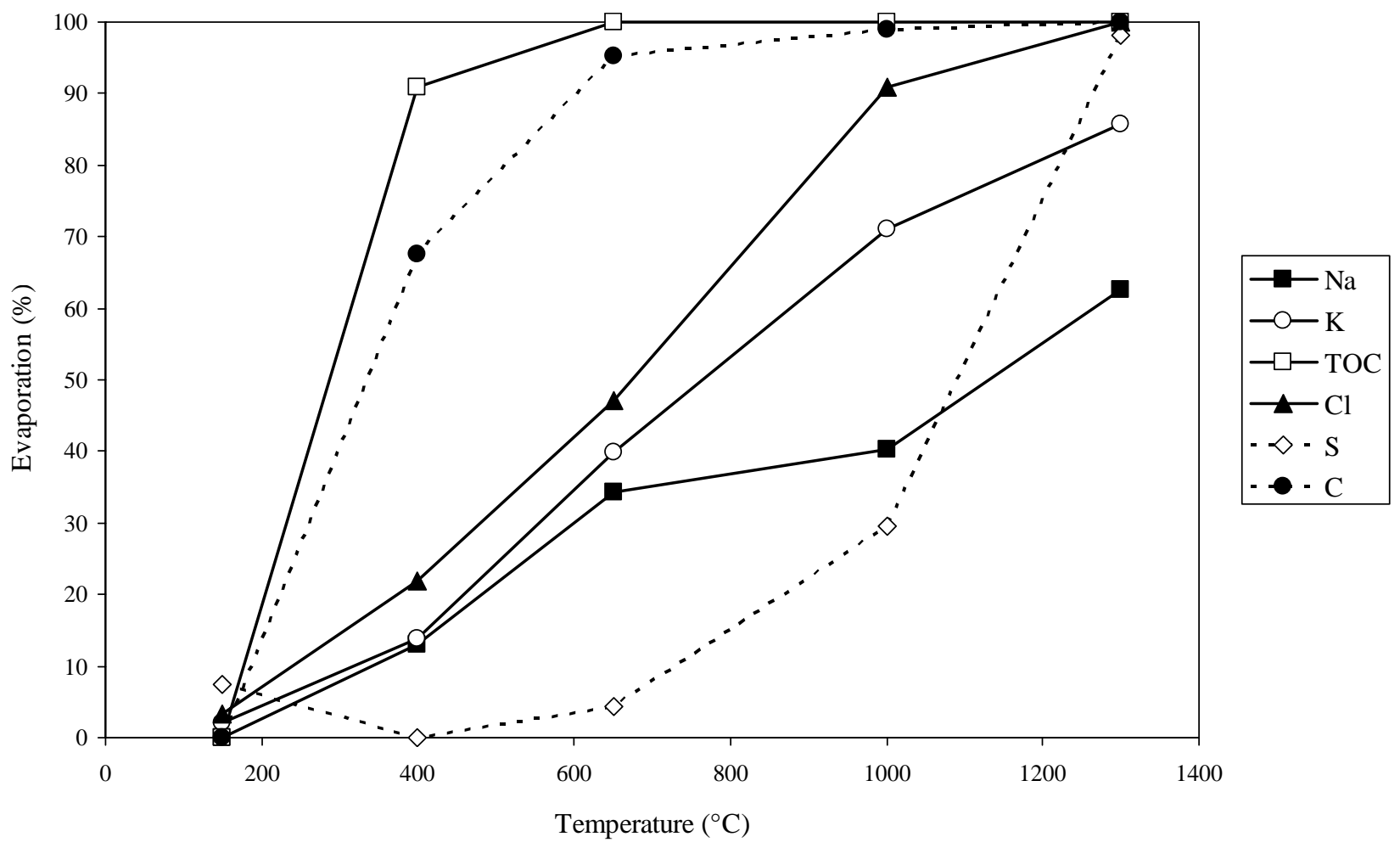


Fig. 5b

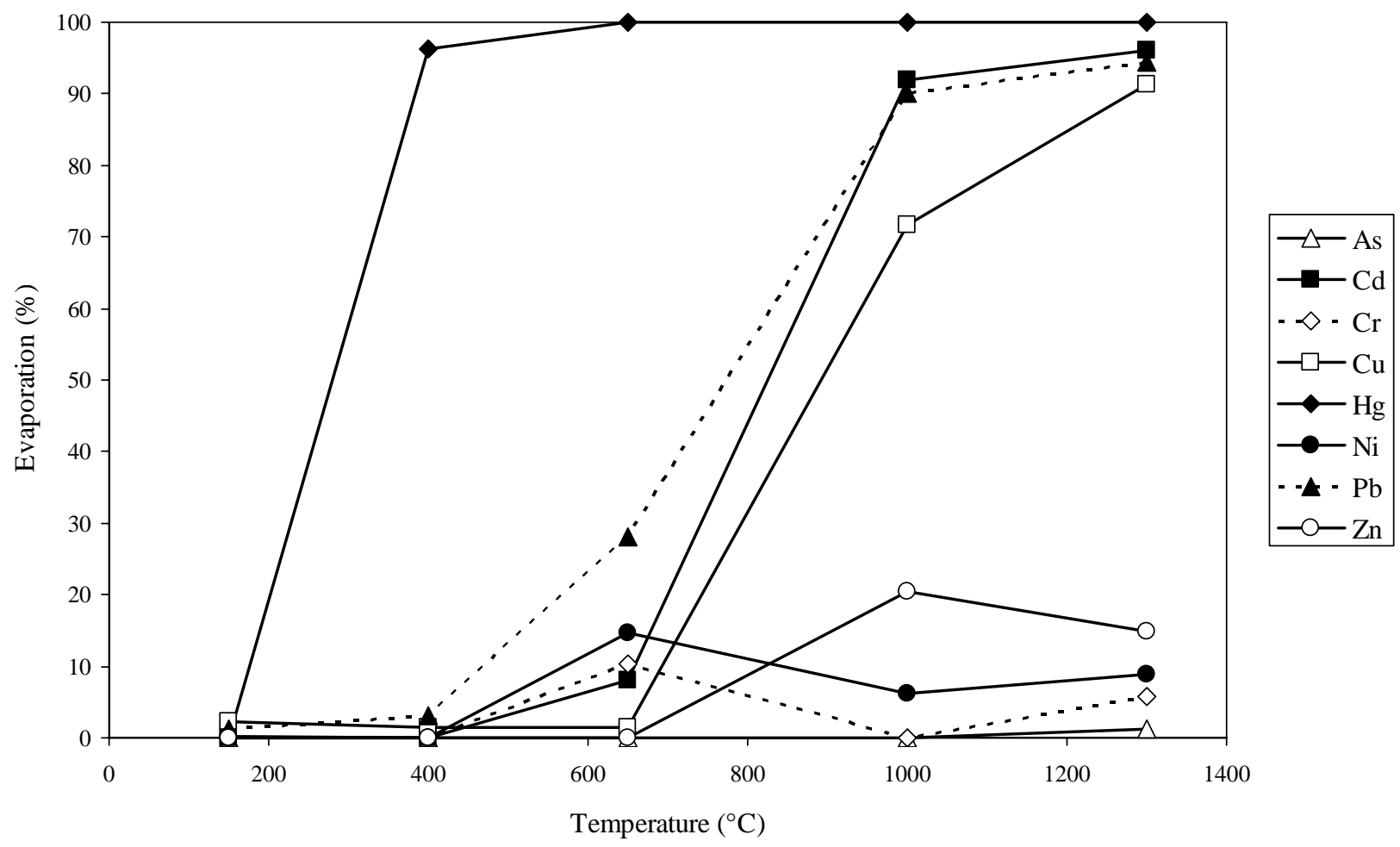

